\title{
Stemcell Transplantation- Types, Risks and Benefits
}

\section{Jeevani $T^{*}$}

Department of Biotechnology, Acharya Nagarjuna University, India

\begin{abstract}
Stem cells are the body's raw materials cells from which all other cells with specialized functions are generated. Under the right conditions in the body stem cells divide to form more cells, called daughter cells. These daughter cells either become new stem cells called self-renewal or become specialized cells i.e. differentiation with a more specific function, such as blood cells, brain cells, heart muscle or bone. Stem cells are unique and no other cell in the body has the natural ability to generate new cell types. Stem cell transplants, also known as bone marrow transplants, have been performed in the United States since the late 1960s. These transplants use adult stem cells. Adult stem cells are being tested in other applications, including a number of degenerative diseases, such as heart failure. Stem cells from umbilical cord blood have been successfully used in clinical trials to treat cancer and blood-related diseases.
\end{abstract}

Keywords: Stem cells; Transplantation; Hematopoietic stem cells; Pluripotential hemopoietic stem cell; Apheresis; cryopreservation; Autologous transplants; Allogeneic transplants; Syngeneic transplants; Graft-versus-cancer; Bone marrow; Engraftment

Abbreviations: HSCs: Hematopoietic stem cells; MSCs: Mesenchymal stem cells; PBSCs: Peripheral blood stem cells; BMT: Bone marrow transplantation; PBSCT: Peripheral blood stem cell transplantation; HSCT: Hematopoietic stem cell transplantation; HLA: Human leukocyte antigen typing; SLE: Systemic lupus erythematosus

\section{Introduction}

Stem cells are cells with the potential to develop into many different types of cells in the body. They serve as a repair system for the body [1]. There are two main types of stem cells, embryonic stem cells and adult stem cells [2]. Stem cells are which have the remarkable potential to develop into many different cell types in the body during early life and growth and dividing essentially without limit to replenish other cells as long as the person or animal is still alive. When a stem cell divides, each new cell has the potential [3] either to remain a stem cell or become another type of cell with a more specialized function, such as a muscle cell, a red blood cell, or a brain cell. Stem cells are distinguished from other cell types by two important characteristics [4]. First, they are unspecialized cells capable of renewing themselves through cell division, [5] sometimes after long periods of inactivity. Second, under certain physiologic or experimental conditions, they can be induced to become tissue- or organ-specific cells with special functions. In some organs, such as the gut and bone marrow, stem cells regularly divide to repair and replace worn out or damaged tissues [6]. In other organs, however, such as the pancreas and the heart, stem cells only divide under special conditions. Human embryonic stem cells [7] are embryos created for reproductive purposes through in vitro fertilization procedures [8]. Another breakthrough by identifying conditions that would allow some specialized adult cells to be "reprogrammed" genetically to assume a stem cell-like state [9].

Transplantation is a technique of replacing the recipient's damaged or absent organ from a donor [10]. A stem cell transplant is the infusion of healthy stem cells into your body. A stem cell transplant may be necessary if your bone marrow stops working and doesn't produce enough healthy stem cells. A stem cell transplant can help your body make enough healthy white blood cells, red blood cells or platelets [11] and reduce your risk of life-threatening infections, anemia [12] and bleeding. The procedure to replenish body's supply of healthy blood- forming cells is generally called a stem cell transplant, it's also known as a bone marrow transplant or an umbilical cord blood transplant, [13] depending on the source of the stem cells. Stem cell transplantation is a very complex process that may span several months [14].

Bone marrow is the soft, sponge-like material found inside bones [15]. It contains immature cells known as hematopoietic or bloodforming stem cells [16]. Hematopoietic stem cells are different from embryonic stem cells [17]. Embryonic stem cells can develop into every type of cell in the body whereas Hematopoietic stem cells divide to form more blood-forming stem cells, or they mature into one of three types of blood cells: White blood cells which fight infection [18]; red blood cells, which carry oxygen; and platelets, which help the blood to clot [19]. Hematopoietic stem cells (HSCs) [20], bone marrow also contains mesenchymal stem [21-23] cells (MSCs). Most hematopoietic stem cells are found in the bone marrow, [24] but some cells, called peripheral blood stem cells (PBSCs), are found in the bloodstream. Hematopoietic stem cells can give rise to at least eight distinct blood cell lineages and can maintain lifelong blood production due to which they can exhibit a property of balancing self-renewal and differentiation [25]. Blood in the umbilical cord also contains hematopoietic stem cells. Cells from any of these sources can be used in transplants. Bone marrow [26] transplantation (BMT) and peripheral blood stem cell transplantation (PBSCT) are procedures that restore stem cells that have been destroyed by high doses of chemotherapy and/or radiation therapy [27].

\section{Hematopoietic Stem Cell Transplantation (HSCT)}

Hematopoietic stem cell transplantation (HSCT) is the transplantation of Pluripotential hemopoietic stem cell or blood, often derived from bone marrow, umbilical cord blood or hematopoietic stem cells derived from a placenta [28-30]. Stem cell transplantation is a medical procedure in the fields of hematology and oncology, most

*Corresponding author: Jeevani T, Department Of Biotechnology, Acharya Nagarjuna University, Guntur, India, E-mail: jeevanithota@yahoo.co.in

Received September 06, 2011; Accepted October 31, 2011; Published November 02, 2011

Citation: Jeevani T (2011) Stemcell Transplantation- Types, Risks and Benefits. J Stem Cell Res Ther 1:114. doi:10.4172/2157-7633.1000114

Copyright: () 2011 Jeevani T. This is an open-access article distributed under the terms of the Creative Commons Attribution License, which permits unrestricted use, distribution, and reproduction in any medium, provided the original author and source are credited. 
often performed for people with diseases of the blood, bone marrow, or certain cancer [31]. With the availability of the stem cell growth factors GM-CSF and G-CSF [32,33], most hematopoietic stem cell transplantation procedures are performed using stem cells collected from the peripheral blood [34] such as cord blood or placenta derived stem cells, rather than from the bone marrow. Collecting peripheral blood stem cells [35] provides a bigger graft, [36] does not require that the donor be subjected to general anesthesia to collect the graft which results in a shorter time to engraftment, and may provide for a lower long-term relapse rate $[37,38]$. Depending upon the donor, the transplantation is called allogeneic, autologous or syngeneic. In each case, the source of these hematopoietic stem cells could be the bone marrow, peripheral blood or umbilical cord blood. Three different types of hematopoietic stem cells can be collected or harvested.

\section{Peripheral blood stem cells}

Peripheral blood stem cells [39] are harvested from donated blood. The stem cells are separated and collected and the rest of the blood is returned to the donor. The stem cells used in PBSCT come from the bloodstream. A process called apheresis or leukapheresis is used to obtain PBSCs [40] for transplantation. For 4 or 5 days before apheresis, the donor may be given a medication to increase the number of stem cells released into the bloodstream. In apheresis, blood is removed through a large vein in the arm or a central venous catheter in which a flexible tube that is placed in a large vein in the neck, chest, or groin area. The blood goes through a machine that removes the stem cells. The blood is then returned to the donor and the collected cells are stored. Apheresis typically takes 4 to 6 hours. The stem cells are then frozen until they are given to the recipient.

\section{Bone marrow stem cells}

Bone marrow stem cells [41] are collected from the patient's hip bone through a surgical procedure. The stem cells used in BMT come from the liquid center of the bone, $[42,43]$ called the marrow. In general, the procedure for obtaining bone marrow, which is called "harvesting," is similar for all three types of BMTs autologous, syngeneic, and allogeneic. The donor is given either general anesthesia, which puts the person to sleep during the procedure, or regional anesthesia, which causes loss of feeling below the waist. Needles are inserted through the skin over the pelvic bone or, in rare cases, the breastbone and into the bone marrow to draw the marrow out of the bone [44]. Harvesting the marrow takes about an hour. The harvested bone marrow is then processed to remove blood and bone fragments. Harvested bone marrow can be combined with a preservative and frozen to keep the stem cells alive until they are needed. This technique is known as cryopreservation [45]. Stem cells can be cryopreserved for many years.

\section{Cord blood stem cells}

Cord blood stem cells [46] are collected from a mother's placenta immediately after a child is born. Stem cells also may be retrieved from umbilical cord blood. After the baby is born and the umbilical cord has been cut, blood is retrieved from the umbilical cord and placenta. This process poses minimal health risk to the mother or the child. If the mother agrees, the umbilical cord blood is processed and frozen for storage by the cord blood bank. Only a small amount of blood can be retrieved from the umbilical cord and placenta, so the collected stem cells are typically used for children or small adults.

\section{Types of Transplants}

The three main types of stem cell transplants are autologous, syngeneic and allogeneic. The type of transplant needed will depend on the patient's specific medical condition and the availability of a matching donor.

\section{Autologous transplants}

In autologous transplants, patients receive their own stem cells, with this type of transplant, patients act as their own donor i.e. a patient who is about to undergo cancer treatment will have his or her own stem cells removed and frozen for later use [47]. After the patient receives chemotherapy and/or radiation, the stem cells are thawed and put back into the patient's body [48]. This procedure may be done once or many times, depending on the need. Sometimes doctors will use extra-high doses of chemotherapy [49] during treatment to kill as many cancer cells [50] as possible if they know a patient will be getting a stem cell transplant soon after [51].

\section{Syngeneic transplants}

In syngeneic transplants [52], patients receive stem cells from their identical twin. Since identical twins represent a small number of births, syngeneic transplantation is rare. Because identical twins have the same genes, they also have the same set of human leukocyte associated antigens. As a result, there is less chance of the transplant being rejected.

\section{Allogeneic transplants}

In allogeneic transplants, patients receive stem cells from their brother, sister, or parent i.e. a person who is not related to the patient called an unrelated donor [53]. With an allogeneic transplant, the stem cells come from a donor often a sibling but sometimes another volunteer whose cells are considered a "match" for the patient. The process of finding a match is called tissue typing or human leukocyte antigen typing. HLA is a protein on the surface of blood cells [54]. Basically, the more "HLA markers" a patient and the potential donor have in common, the greater the chance that the transplant will be successful. Advantage of allogeneic stem cell transplant is that the donor stem cells make their own immune cells, which may help destroy any cancer cells [55] that may remain after high-dose treatment. This is called the graft-versus-cancer effect $[56,57]$.

\section{Mechanism of Transplantation}

After being treated with high-dose anticancer drugs and/or radiation, the patient receives the stem cells through an intravenous (IV) line just like a blood transfusion. This part of the transplant takes 1 to 5 hours. After entering the bloodstream, the stem cells travel to the bone marrow, where they begin to produce new white blood cells, red blood cells, and platelets in a process known as "engraftment." Engraftment [58-60] usually occurs within about 2 to 4 weeks after transplantation. It can be observed by checking blood counts on a frequent basis [61].

\section{Risk Associated with Donation}

In bone marrow donation only a small amount of bone marrow is removed, donating usually does not pose any significant problems for the donor [62]. The most serious risk involves the use of anesthesia $[63,64]$ during the procedure. The area where the bone marrow was taken out may feel stiff or sore for a few days, and the donor may feel 
tired [65]. Within a few weeks, the donor's body replaces the donated marrow; however, the time required for a donor to recover varies. Some people are back to their usual routine within 2 or 3 days, while others may take up to 3 to 4 weeks to fully recover their strength. In peripheral blood stem cell donation [66], Apheresis usually causes minimal discomfort. During apheresis, the person may feel lightheadedness, chills, numbness around the lips, and cramping in the hands [67]. Unlike bone marrow donation, PBSC donation does not require anesthesia. The medication that is given to stimulate the mobilization of stem cells from the marrow into the bloodstream may cause bone and muscle aches, headaches, fatigue, nausea, vomiting, and/or difficulty sleeping $[68,69]$. These side effects generally stop within 2 to 3 days of the last dose of the medication. Unlike with an autologous transplant, there is a risk of rejection. Sometimes, though donor [70] being a good match, the transplant simply may not take. Other times, the donor cells can begin to make immune cells that attack the recipient's body. This condition is called graft-versus-host disease [71], and can be quite serious. Fortunately, most cases are successfully treated with steroids [72] and other medications. Sometimes, an upside of graft-versus-host disease is that the newly transplanted cells recognize the body's cancer cells [73] as different or foreign, and actually work to fight them. One advantage of autologous stem cell transplant is that you are getting your own cells back. This means there is no risk that your immune system [74] will reject the transplant or that the transplanted cells will attack or reject your body. Another common disease which is common is Graft-versus-host disease is a distinct syndrome which involves the development of skin rash, diarrhea, abdominal pain and hepatitis [75] jaundice within the first 100 days after an allogeneic bone marrow transplant. High-dose immunosuppressive therapy with autologous hematopoietic stem cell transplantation showed good results in the treatment of severe autoimmune diseases [76].

\section{Benefits}

Advancements in stem cell therapies and tissue engineering hold great promise for regenerative medicine [77]. Stem cell transplants are used for treating patients whose stem cells have been damaged [78] by disease or for treating the disease. Stem cell transplants with kidney damage from pyelonephritis a type of urinary infection that has reached the kidney was found to improve kidney structure and function [79]. In various studies it's proved that the patients remained free from systemic lupus erythematosus (SLE) and improved continuously after highdose chemotherapy [80] and hematopoietic stem-cell transplantation $[81,82]$. BMT and PBSCT are most commonly used in the treatment of leukemia [83] and lymphoma. They are most effective when the leukemia [84] or lymphoma is in remission i.e. the signs and symptoms of cancer have disappeared [85]. BMT and PBSCT are also used to treat other cancers such as neuroblastoma i.e. cancer that arises in immature nerve cells and affects mostly infants and children and multiple myeloma [86]. Donor stem cell transplantation may be an effective treatment for high risk myeloma patients with certain chromosomal abnormalities was proved recently. Autologous adult stem cell transplantation has been the latest tool in regenerative medical therapy and in cardiovascular diseases $[87,88]$. Autologous transplantation seems to be superior to both chemotherapy [89] and allogeneic transplantation for treatment of multiple myeloma but Syngeneic transplantation appears to be as good as autologous transplantation and therefore it is used to perform in patients with the disease whenever there is an identical twin donor available [90].

\section{Conclusion}

Stem cell transplantation is a kind of medicine for cancer; here very high doses of chemo are used, often along with radiation therapy, to try to destroy all of the cancer. This treatment also kills the stem cells in the bone marrow. Advantage of autologous stem cell transplant is that the patient will be getting his/her own cells back. Advantage of allogeneic stem cell transplant is that the donor stem cells make their own immune cells, which may help destroy any cancer cells that may remain after high-dose treatment. Another possible advantage is that the donor can often be asked to donate more stem cells or even white blood cells if needed. Stem cells from healthy donors are also free of cancer cells. Soon after treatment, stem cells are given to replace those that were destroyed. These stem cells are given into a vein, much like a blood transfusion. Syngeneic transplants won't help destroy any remaining cancer cells because the new immune system is so much like yours. Every effort must be made to destroy all the cancer cells before the transplant is done to help keep the cancer from coming back. The Food and Drug Administration has approved an initial safety study using an embryonic stem cell therapy for the treatment of serious spinal cord injuries. Researchers are evaluating BMT and PBSCT in clinical trials for the treatment of various types of cancer.

\section{References}

1. Ghodsizad A, Voelkel T, Moebius JM, Gregoric I, Bordel V, et al. (2010) Biological Similarities Between Mesenchymal Stem Cells (Mscs) and Fibroblasts. J Cytol Histol 1: 101.

2. Valarmathi MT, Fuseler JW (2011) Mammalian Cardiac Muscle Regeneration: Structural and Functional Modulation of Adult Marrow Stromal Stem Cells. Anatom Physiol 1: e102.

3. Lionetti V (2011) How Resident Stem Cells Communicate with Cardiac Cells in Beating Heart? J Stem Cell Res Ther 1: e104.

4. Ponnusamy MP (2010) Stem Cell Research and Cancer Stem Cells. J Tissue Sci Eng 2: 104e.

5. Canelles M (2011) The Universality of Asymmetric Division. J Stem Cell Res Ther 1: e103.

6. Pei M, He F, Wei L (2010) Three-Dimensional Cell Expansion Substrate For Cartilage Tissue Engineering And Regeneration: A Comparison In Decellularized Matrix Deposited By Synovium-Derived Stem Cells And Chondrocytes. J Tissue Sci Eng 2: 104.

7. Meregalli M, Farini A, Torrente $Y$ (2011) Mesenchymal Stem Cells as Muscle Reservoir. J Stem Cell Res Ther 1: 105

8. Kim CH (2011) Strategies for Poor Responders in IVF Cycles. Reproductive Sys Sexual Disord S5: 1.

9. Shrihari TG (2011) Cancer Stem Cells - Therapeutic Boon! J Cancer Sci Ther 3: 197-200.

10. Delavari M, Shahabi-Nejad N, Renzaho AMN, Zahedi MJ, Owhadi AR (2011) Frequency of Anti-HBc \& HBV DNA detection in blood donors of Kerman province, Iran. J Blood Disord Transfus 2: 105

11. Emara E, Abdel-Sater KA (2011) Beneficial Effects of Calcium Channel Blocker "Nifedipine" on Abnormalities of Platelets and Lipid Metabolism in Patients with Type II Diabetes Mellitus. J Diabetes Metab 2: 131

12. Demmouche A, Khelil S, Moulessehoul S (2011) Anemia Among Pregnant Women in the Sidi Bel Abbes Region (West Alegria) : An Epidemiologic Study. J Blood Disord Transfus 2: 113

13. Vitin AA, Martay K, Vater Y, Dembo G, Maziarz M (2010) Effects of Vasoactive Agents on Blood Loss and Transfusion Requirements During Pre-Reperfusion Stages of the Orthotopic Liver Transplantation. J Anesthe Clinic Res 1: 104.

14. Shahin Rafii, David Lyden (2003) Therapeutic Stem and progenitor cel transplantation for organ vascularization and regeneration. Nat Med 9: 702 712. 
15. Sollazzo V, Palmieri A, Girardi A, Farinella F, Carinci F (2011) Trabecular Titanium Induces Osteoblastic Bone Marrow Stem Cells Differentiation. J Biotechnol Biomaterial 1: 102

16. http://stemcells.nih.gov/staticresources/info/scireport/PDFs/D. $\% 20$ Chapter\%202.pdf

17. Patel R, Lomax G (2011) Use of hESC Lines by CIRM Grantees: The Value of Embryonic Stem Cell Research Oversight (ESCRO) Committees. J Stem Cell Res Ther 1: 107.

18. Gentile P, Scioli MG, Orlandi A, Cervelli V (2011) Review: Application of Platelet-Rich Plasma in Hard Tissue Defects. J Tissue Sci Eng S2: 1.

19. Horie M, Ito A, Kawabe Y, KamihiraM (2011) A Genetically Engineered STO Feeder System Expressing E-Cadherin and Leukemia Inhibitory Factor for Mouse Pluripotent Stem Cell Culture. J Bioprocess Biotechniq S3: 1.

20. Ratajczak MZ, Kim CH (2011) Bioactive Sphingolipids and Complement Cascade as New Emerging Regulators of Stem Cell Mobilization and Homing. J Stem Cell Res Ther 1: e102.

21. Katarina Le Blanc, Olle Ringdén (2004) Immunobiology of Human Mesenchymal Stem Cells and Future Use in Hematopoietic Stem Cell Transplantation. Biol Blood Marrow Transplant 11: 321-334.

22. Mittal R (2011) Mesenchymal Stem Cells: The New Players in the Pathogenesis of Tuberculosis. J Microbial Biochem Technol 3: ii-0.

23. Silvani G, Galli D, Benedetti L, Ceccarelli G, Crosetto N, et al. (2011) Peculiar Characteristics of Human Mesenchymal Stem Cell Clones Suitable as Tissue Engineering Models. J Tissue Sci Eng 2: 106.

24. Kondo M, Wagers AJ, Manz MG, Prohaska SS, Scherer DC, et al. (2003) Biology Of Hematopoietic Stem Cells And Progenitors: Implications for Clinical Application. Annu Rev Immunol 21: 759-806.

25. Phillips RL, Ernst RE, Brunk B, Ivanova N, Mahan MA, et al. (2000) The Genetic Program of Hematopoietic Stem Cells. Science 288: 1635-1640.

26. William JB, Prabakaran R, Ayyappan S, Puskhinraj H, Rao D, et al. (2011) Functional Recovery of Spinal Cord Injury Following Application of Intralesional Bone Marrow Mononuclear Cells Embedded in Polymer Scaffold - Two Year Follow-up in a Canine. J Stem Cell Res Ther 1: 110.

27. Satyavani R, Fatima A, Sundaram CS, Anabalagan C, Saritha CV, et al. (2009) Proteomic Analysis Of The "Side Population" (SP) Cells From Murine Bone Marrow. J Proteomics Bioinform 2: 398-407.

28. Smith C (2003) Hematopoietic Stem Cells and Hematopoietic. Cancer Contro 10: $9-16$.

29. http://web.mit.edu/7.01x/7.012/pdfs/Hematopoiesis_stem_cells.pdf

30. Grant MB, May WS, Caballero S, Brown GA, Guthrie SM, et al. (2002) Adult hematopoietic stem cells provide functional hemangioblast activity during retinal neovascularization. Nat Med 8: 607-612.

31. Singh RK, Sudhakar A, Lokeshwar BL (2011) From Normal Cells to Malignancy: Distinct Role of Pro-inflammatory Factors and Cellular Redox Mechanisms. J Cancer Sci Ther 3: 70-75.

32. Abdel Aziz MT, Wassef MA, Rashed LA, Mhfouz S, Omar N, et al. (2011) Mesenchymal Stem Cells Therapy in Acute Renal Failure: Possible Role of Hepatocyte Growth Factor. J Stem Cell Res Ther 1: 109.

33. Geisbauer CL, Chapin JC, Wu BM, Dunn JCY (2011) Transplantation of Enteric Cells into the Rodent Stomach with Basic Fibroblast Growth Factor. J Cell Sci Ther 2: 103.

34. Razmkhah M, Jaberipour M, Ghaderi A (2011) Chemokines and Chemokine Receptors Expression in the Adipose Derived Stem Cells (ASCs), Breas Tissues and in Peripheral Blood of Patients with Breast Cancer. J Carcinogene Mutagene 2: 120

35. Dimeo FC, Tilmann MH, Bertz H, Kanz L, Mertelsmann R, et al. (1997) Aerobic Exercise in the Rehabilitation of Cancer Patients after High Dose Chemotherapy and Autologous Peripheral Stem Cell Transplantation.Cancer 79: 1717-1722.

36. Copelan EA (2006) Hematopoietic Stem-Cell Transplantation. N Engl J Med 354: 1813-1826.

37. Abdel-Hady EE, El-Toony MM, Abdel-Hamed MO, Hammam AM (2011) Grafting of Styrene onto Commercial PTFE Membrane and Sulfonation for Possible Use in Fuel Cell. J Membra Sci Technol 1: 108.
38. Bona RD, De Caterina AR, Leo M, Biasillo G, Basile E (2011) Statins Reduce Incidence of Early Perioperative Complications and Length of in-Hospital Stay after Coronary Artery Bypass Graft Surgery. J Clinic Experiment Cardiol 2: 137.

39. http://www.mayoclinic.com/health/stem-cells/CA00081

40. Weaver CH, Buckner CD, Longin K, Appelbaum FR, Rowley S, et al. (1993) Syngeneic Transplantation with Peripheral Blood Mononuclear Cells Collected After the Administration of Recombinant Human Granulocyte ColonyStimulating Factor. Blood 82: 1981-1984.

41. Wilson A, Trumpp A (2006) Bone-marrow haematopoieticstem- cell niches. Nat Rev Immunol 6: 93-106.

42. Gottlieb H, Klausen TW, Boegsted M, Olsen BS, Lausten GS, et al. (2011) A Clinical Study of Circulating Cellular and Humoral Biomarkers Involved in Bone Regeneration Following Traumatic Lesions. J Stem Cell Res Ther 1: 108.

43. Hwang J, Lee S, Park H, Kim M (2010) Autologous Bone Marrow Transplantation in Osteonecrosis of the Femoral Head. J Tissue Sci Eng 2: 103.

44. Argento MA, Manara LRB, Berni VC, Cortelazzo AL (2010) Flapless Technique for Periodontal Bone Grafts in Treatment of Severe Periodontitis. Presentation and Long-Term Retrospective Study. J Microbial Biochem Technol 2: 107-110.

45. Ito $J$ (2011) What contributes to the success of in vitro fertilization using cryopreserved spermatozoa in rodents? J Fertiliz In Vitro 1: e102.

46. http://www.cancer.org/acs/groups/cid/documents/webcontent/003215-pdf.pdf

47. Loudon JA (2011) Harvesting the Benefits of Understanding Cancer with the Use of 'Shuttle' Era Technology- Cellular Survival Strategies and Tissue Engineering Via Grafting of Genetically Immortalized Autologous Cells. J Bioanal Biomed S5: 1.

48. Duran JM, George JC (2011) A Review of the Basis of Autologous Stem Cell Therapy for Coronary Artery Disease. J Clinic Experiment Cardiol 2: 130.

49. Yokoe H, Kasamatsu A, Ogawara K, Ishigami T, Sato Y, et al. (2010) Neoadjuvant Chemotherapy with S-1 for Patients with Oral Squamous Cell Carcinoma. J Cancer Sci Ther 2: 132-135.

50. Miceli V, Cocciadiferro L, Maurizio Z, Kang KS, Trosko JE, et al. (2011) Molecular Profiling of Potential Human Prostate Cancer Stem Cells. J Stem Cell Res Ther S7: 1 .

51. Bang OY, Lee JS, Lee PH, Lee G (2005) Autologous mesenchymal stem cell transplantation in stroke patients. Ann of Neurol 57: 874-882.

52. Engman CA, Hill JM, Meehan KR (2009) Syngeneic Transplant in Mantle Cell Lymphoma: A Rare Event and Review of the Literature. Clin Adv Hemato Oncol 7: 321-324.

53. Harring TR, Nguyen NT, Goss JA, O'Mahony CA (2011) Human T-Cell Lymphoma Virus-Positive Allograft Used For Effective Orthotopic Live Transplantation: A Case Report and Review of the Literature. J Transplant Technol Res 1: 102.

54. Dai W, Hale SL, Martin BJ, Kuang JQ, Dow JS, et al. (2005) Allogeneic Mesenchymal Stem Cell Transplantation in Postinfarcted Rat Myocardium Short- and Long-Term Effects. Circulation 112: 214-223.

55. Rameshwar P (2011) Post-identification of Cancer Stem Cell: Ethical and Scientific Dilemmas in Therapeutic Development? J Stem Cell Res Ther 1: e101.

56. Mielcarek M, Martin PJ, Leisenring W, Flowers ME, Maloney DG, et al. (2003) Graft-versus-host disease after nonmyeloablative versus conventional hematopoietic stem cell transplantation. Blood 102: 756-762.

57. Przepiorka D, Smith TL, Folloder J, Khouri I, Ueno NT, et al. (1999) Risk Factors for Acute Graft-Versus-Host Disease After Allogeneic Blood Stem Cell Transplantation. Blood 94: 1465-1470.

58. Tseng SC, Prabhasawat P, Barton K, Gray T, Meller D (1998) Amniotic Membrane Transplantation With or Without Limbal Allografts for Corneal Surface Reconstruction in Patients With Limbal Stem Cell Deficiency. Arch Ophthalmol 116: 431-441.

59. Salman AG (2010) Value of Fresh Amniotic Membrane Graft in Management of Resistant Non Infected Corneal Ulcer. J Clinic Experiment Ophthalmol 1: 108.

60. Mandour SS, Kakizaki H, Farahat HG, Hegazi KA, EI Saadany AKI, et al. (2011) Use of Modified Hughes Flap versus Auricular Cartilage Graft for Replacement 
of Posterior Lamella in Lower Eyelid Reconstruction. J Clinic Experiment Ophthalmol 2: 190

61. Mimura T, Yamagami S, Yokoo S, Usui T, Amano S (2011) Prospects for Descemet Stripping Automated Endothelial Keratoplasty Using Cultured Human Corneal Endothelial Cells. J Transplant Technol Res S2: 1.

62. Minguell JJ, Pereira A, Bartholomew P, Lasala GP (2011) The Intrathecal Infusion of Mesenchymal Stem Cells into Healthy Rabbits is Safe and Devoid of Neurological or Clinical Complications. J Stem Cell Res Ther 1: 104.

63. Balick Weber CC, Brillouet Banchereau AC, Blanchet AD, Blanchet $P$, Safar ME, et al. (2011) General Anesthesia in Hypertensive Patients: Impact of Pulse Pressure but not Cardiac Diastolic Dysfunction on Intraoperative Hemodynamic Instability. J Anesthe Clinic Res 2: 114.

64. Zoremba M, Kalmus G, Steinfeldt T, Müler H, Wulf H, et al. (2010) Respiratory Impairment in the Obese Following General Anesthesia - Impact of Anaesthesia and Patient Related Factors. J Anesthe Clinic Res 1: 108

65. Lins Kusterer LEF (2011) Oral Diseases and Liver Pre and Post-Transplantation Disorders. J Transplant Technol Res S1: 1.

66. Porrata LF, Inwards DJ, Ansell SM, Micallef IN, Johnston PB, et al. (2011) Day 15 Peripheral Blood Lymphocyte/monocyte Ratio Postautologous Peripheral Hematopoietic Stem Cell Transplantation and Survival in Diffuse Large B-cell Lymphoma. J Stem Cell Res Ther 1: 103.

67. Waterman Ruth S, Betancourt AM (2011) Treating Chronic Pain with Mesenchymal Stem Cells: A Therapeutic Approach Worthy of Continued Investigation. J Stem Cell Res Ther S2: 1.

68. Yıldırım YS, Apuhan T, Ersözlü T, Bahar | (2011) Effects of Anesthesia on Patients Undergoing Surgery for Obstructive Sleep Apnea. J Anesthe Clinic Res S7: 1.

69. Lal C, Strange C (2011) Obstructive Sleep Apnea Syndrome, Hypoxemia and Endothelial Dysfunction: One Disease or Many? J Pulmonar Respirat Med 1: 101

70. Afaneh C, Ramasamy R, Aull MJ, Leeser DB, Sosa RE, et al. (2011) The Evolution of Laparoscopic Right Donor Nephrectomy: Progression to Single Site Surgery. J Transplant Technol Res 1: 103.

71. Latif T, Pohlman B, Kalaycio M, Sobecks R, Hsi ED, et al. (2003) Syngeneic graft-versus-host disease: a report of two cases and literature review. Bone Marrow Transplant 32: 535-539.

72. Yadav M, Durga P, Gopinath R (2011) Role of Steroids in Prevention of Pain on Propofol Injection. J Anesthe Clinic Res 2: 132.

73. Cruz M, Siden A, Tasat DR, Yakisich JS (2010) Are all Glioma Cells Cancer Stem Cells? J Cancer Sci Ther 2: 100-106

74. Saikh KU (2011) Innate Immunity and Sepsis: MyD88 as a Target for Therapeutics. J Clin Cell Immunol 2: e102.

75. Mukherjee S (2009) Antiviral Therapy for Hepatitis B in Preand Post-liver Transplant Patients. J Antivir Antiretrovir 1: 17-27.

76. Novik AA, Kuznetsov AN, Melnichenko VY, Fedorenko DA, lonova TI, et al. (2011) Non-myeloablative Autologous Haematopoietic Stem Cell Transplantation with Consolidation Therapy using Mitoxantrone as a Treatment Option in Multiple Sclerosis Patients. J Stem Cell Res Ther 1: 102

77. Irioda AC, Zocche L, Souza CMCO, Ferreira RJ, Aliprandini E, et al. (2011) Pap Test as the First Step in Screening Genetic Stability in Cell- Based Therapy. J Stem Cell Res Ther 1: 106.

78. Yu L, Ma J, Ma R, Zhang Y, Zhang X, et al. (2011) Repair of Excitotoxic Neuronal Damage Mediated by Neural Stem Cell Lysates in Adult Mice. J Cell Sci Ther 2: 109.

79. Harring TR, Kuten DA, Nguyen NT, Goss JA, O'Mahony CA (2011) Orthotopic Liver Transplantation in Patients with Mixed Hepatocellular Carcinoma Cholangiocarcinoma. J Transplant Technol Res 1: 104

80. Essadi I, Sbitti Y, Ichou M, Errihani H (2011) The Role of Chemotherapy in the Treatment of Kaposi's Sarcoma. J Cancer Sci Ther 3: 145-148.

81. A Traynor AE, Schroeder J, Rosa RM, Cheng D, Stefka J, et al. (2000) Treatment of severe systemic lupus erythematosus with high-dose chemotherapy and haemopoietic stem-cell transplantation: a phase I study. Lancet 356: 701-707.

82. Burt RK, Testori A, Craig R, Cohen B, Suffit R, et al. (2008) Hematopoietic stem cell transplantation for autoimmune diseases: What have we learned? J Autoimmun 30: 116-120.

83. Yadav B, Greish K (2011) Selective inhibition of hemeoxygenase-1 as a nove therapeutic target for anticancer treatment. J Nanomedic Nanotechnol S4: 5 .

84. Verma D, Agarwal K, Wadhwa M, Shukla S, Prakash O (2011) T-Cell Lymphoblastic Lymphoma/Leukemia of Tenon's Capsule of Eye: AnUnusual Presentation. J Clinic Experiment Ophthalmol 2: 189.

85. Avramidis D, Cruz M, Sidén Å, Tasat DR, Yakisich JS (2009) Regrowth Concentration Zero (RC0) as Complementary Endpoint Parameter to Evaluate Compound Candidates During Preclinical Drug Development for Cancer Treatment. J Cancer Sci Ther 1: 19-24.

86. Jayashankar E, Roshinipaul T (2010) Prognostication of Histomorphological Characteristics in Multiple Myeloma. J Cancer Sci Ther 2: 153-156.

87. Patel AN, Geffner L, Vina RF, Saslavsky J, Urschel HC, et al. (2005) Surgical treatment for congestive heart failure with autologous adult stem cel transplantation: A prospective randomized study. J Thorac Cardiovasc Surg 130: $1631-1638$

88. White HS, Smith L, Gentry T, Balber AE (2011) Mechanisms of Action of Human Aldehyde Dehydrogenase Bright Cells in Therapy of Cardiovascular Diseases: Expression Analysis of Angiogenic Factors and Aldehyde Dehydrogenase Isozymes. J Stem Cell Res Ther S1: 1.

89. Meyer JE, Cohen SJ (2011) Beyond First-Line Therapy: Combining Chemotherapy and Radioembolization for Hepatic Colorectal Metastases. J Nucl Med Radiat Ther 2: 103

90. Gahrton G, Svensson H, Björkstrand B, Apperley J, Carlson K, et al. (1999) Syngeneic transplantation in multiple myeloma - a case-matched comparison with autologous and allogeneic transplantation. Bone Marrow Transplant 24 741-745. 